Volume 8, Issue 1, 349 - 360.

ISSN: 2165-8714

http://www.eu-jer.com/

\title{
Relationship between Academicians' Organizational Identification Levels and Cynicism Attitudes in Sports Sciences
}

\author{
Cagdas Caz * \\ Yozgat Bozok University, TURKEY
}

\author{
Sait Bardakci \\ Sivas Cumhuriyet University, TURKEY
}

Received: December 2, 2018 - Revised: December 29, 2018 • Accepted: January 12, 2019

\begin{abstract}
This study aims to analyze whether academics' organizational cynicism attitudes and levels of organizational identification in the field of sports sciences differ based on certain variables and determine if any relationship exists between these two variables. "Organizational Cynicism Scale" and "Academics' Organizational Cynicism Scale" were applied to 106 academics as a data collection tool. Mann-Whitney U test and Kruskal Wallis test were used for nonparametric statistical data analysis. Bonferroni correction was taken into account in order to identify different groups. Spearman order correlation coefficient was calculated in order to identify the correlations among variables. The findings suggest that academics' organizational cynicism and identification sub-dimensions did not display significant differences in terms of gender, marital status and academic title. However, significant differences were found among some sub-dimensions in terms of sufficiency of institution's physical facilities, the status of place where the institution is located and financial aid from the institution. Additionally, negative and moderately significant correlations were found between all sub-dimensions of organization cynicism attitude and cognitive/behavioral/affective organizational identification subdimensions. It is considered that the present study will make important contributions to educational psychology thanks to its findings.
\end{abstract}

Keywords: Organizational cynicism, organizational identification, Mann-Whitney U, Kruskal Wallis.

To cite this article: Caz, C., \& Bardakci, S. (2019). Relationship between academicians' organizational identification levels and cynicism attitudes in sports sciences. European Journal of Educational Research, 8(1), 349-360. doi: 10.12973/eu-jer.8.1.349

\section{Introduction}

Organizations are complex structures which are established to achieve a certain goal and succeed in achieving their goals (Topaloglu, 2010). Individuals are members of their institutions, and should consider themselves as an element of that institution. An employee's identification with their institution will result in behaviors that overlap intrainstitutional goals, which helps the individual to meet on a common ground with their institution (Oz \& Bulutlar, 2009). In this respect, organizational identification bears importance in order for an organization to function efficiently (Eroglu, 2008). It is defined as the perception of belonging or solidarity which involves success and failure (Turunc \& Celik, 2010). In other words, organizational identification denotes the continuous integration and harmonization process of an individual's goals into organization goals (Barutcu, 2015). There are numerous factors related to organization identification, one of which is organization cynicism. The concept of cynicism emerged in Ancient Greece around 500 B.C. as a school of thought and lifestyle (Brandes, 1997; Mantere \& Martinsuo, 2001; Metzger, 2004). It expresses employees' belief that their organization lacks unity and integrity, negative emotions such as anger and hate caused by this belief and, along with these emotions, resulting behaviors such as harsh criticism and satirical humor towards the organization (Dean et al. 1998).

Cynicism in academic institutions occur when deep-rooted academic culture is interrupted by constant efforts of change, and academics prioritize their self-interests over academic ideals (Ramaley, 2002). If cynicism is prevalent in a university, academics are often observed to strongly resist against organization changes (Qian \& Daniels 2008). Negative situations such as employee withdrawal, decreasing work productivity and organizational commitment are often witnessed in institutions where organizational cynicism exists.

It is of vital importance for academics to identify themselves with their higher education institutions because they work in an educational organization. The role of identification in productive teaching and training activities and adoption of organization culture and belonging is undeniable. Similar to organizational identification which is an important and useful factor for ensuring organizational/institutional success and continuity, there are also various factors that lead to

\footnotetext{
* Corresponding author:

Cagdas Caz, Yozgat Bozok University, School of Physical Education and Sports, Turkey.

$\triangle$ cazcagdas@gmail.com
} 
institutional/organization failure such as organizational cynicism, which causes employees in an institution/organization to develop negative attitudes towards their institution and colleagues. Therefore, an organization needs a high level of organizational identification and a low level of cynicism among its members for continuous success.

The present study is expected to offer valuable insight into above-mentioned positive and negative concepts, which makes it a valuable article in the literature and shows guidance for further studies in the future. As a result, the present study aims to analyze whether academics' organizational cynicism attitudes and levels of organization identification in the field of sports sciences differ based on certain variables and determine if any relationship exists between these two concepts.

\section{Methodology}

\section{Research Model}

Correlational survey model, which is one of the general survey models, was used as a method in the present study. General survey models are applied to a population or a group of samples in a given population in order to reach generalizations about that population. On the other hand, correlational survey models aim at identifying the existence or degree of covariance between two or more variables (Karasar, 2006). Because the present study aims to analyze the relationship between organizational cynicism attitudes and levels of organizational identification among academics working in the field of sports sciences, correlational survey model was preferred.

\section{Study Group}

The study group consists of 106 academics working at School of Physical Education and Sports and Faculty of Sports Sciences at various universities in Turkey. This study group was selected using convenience sampling method, which is an easier, more cost-effective and faster data collection tool compared to other sampling methods (Gurbuz \& Sahin, 2014).

\section{Data Collection Tools}

Two different scales, Organizational Cynicism Scale adapted to Turkish context by Kalagan (2009) and Instructor's Organizational Identification Scale adapted to Turkish context by Eker (2015), were used as a data collection tool in the present study.

\section{Organizational Cynicism Scale}

Organizational Cynicism Scale adapted to Turkish context by Kalagan (2009) was used in the present study in order to measure academics' level of organization cynicism. It is a 5-point Likert type scale consisting of 13 items and three subdimensions, which are "Cognitive Cynicism", "Affective Cynicism" and "Behavioral Cynicism". The responses to the scale range from negative to positive as "Strongly Disagree", "Disagree" "Partially Agree", "Agree" and "Strongly Agree". There are no reverse coded items in the scale.

\section{Academics' Organizational Identification Scale}

Academics' Organizational Identification Scale adapted to Turkish context by Eker (2015) was used in the present study in order to academics' levels of organizational identification. It is a 5-point Likert type scale consisting of 13 items and two sub-dimensions, which are "Cognitive-Behavioral-Affective Identification" and "Perceived Organizational External Prestige". The responses to the scale range from negative to positive as "Strongly Disagree", "Disagree" "I Don't Know", "Agree" and "Strongly Agree". There are no reverse coded items in the scale.

\section{Data Collection and Scoring}

In the present study, both scales and an additional personal information form were applied to 106 academics, and the data were collected between February 2018 and May 2018 by the researchers. Data collection tools were applied to academics through an online questionnaire. Responses to both scales were scored from 1 (negative) to 5 (positive). Mean scale scores and mean sub-dimension scores were calculated using the sum of total item scores divided by the number of items.

\section{Statistical Methods}

Whether mean scale and sub-dimension scores display a normal distribution was taken into account in order to select statistical methods to be used in the present study. It was understood from Kolmogorov-Smirnov test that all variables did not display a normal distribution. Therefore, it was decided to use non-parametric statistical methods. In this respect, the number of groups was taken into consideration to compare mean sub-dimension scores of different groups in both scales. Accordingly, while Mann-Whitney U test was used to compare mean scores of two independent groups, Kruskal-Wallis test was used to compare mean scores of three or more groups. In case of any differences found in Kruskal-Wallis test, a binary Mann-Whitney U test was performed among groups to find out which group caused a difference. Bonferroni Correction was used to determine the level of significance for Mann-Whitney U tests. As a result, the level of significance was calculated with $\alpha=.05$ divided by the number of binary comparisons. 
Finally, Spearman order correlation coefficient was taken into account in order to analyze the relationship between academics' organizational cynicism sub-dimensions and organizational identification sub-dimensions. According to Buyukozturk (2010), while a correlation coefficient between -1 and 0 denotes a negative correlation between two variables, a value between 0 and +1 denotes a positive correlation. In addition, an absolute value of correlation coefficient between 0.70 and 1.00 means a high correlation, whereas a value between 0.30 and 0.70 and 0.00 and 0.30 means moderate and low correlation, respectively. IBM SPSS 23 package program was used to apply these statistical methods.

\section{Findings}

As shown in Table 1, Cronbach Alpha coefficients, mean sub-dimension scores and standard deviation values of both scales were calculated in order to test the reliability of the data and determine participants' level of organizational cynicism and identification based on the responses given by 106 academics.

Table 1: Cronbach $\alpha$ Coefficients of Scales and Their Sub-dimensions

\begin{tabular}{llcccc}
\hline \multicolumn{1}{c}{ Scales and Their Sub-dimensions } & $\begin{array}{c}\text { Number of } \\
\text { Variables }\end{array}$ & Mean & $\begin{array}{c}\text { S.D. } \\
\text { Coefficient }\end{array}$ & $\begin{array}{c}\text { Cronbach } \boldsymbol{\alpha} \\
\text { Coontion }\end{array}$ \\
\hline \multirow{3}{*}{ Sub-Dimensions } & Cognitive Cynicism & 5 & 2.56 & 0.84 & 0.819 \\
& Affective Cynicism & 4 & 2.62 & 0.80 & 0.713 \\
& Behavioral Cynicism & 4 & 2.75 & 0.85 & 0.747 \\
\hline \multirow{2}{*}{ Sub-Dimensions } & Cognitive-Behavioral-Affective & 10 & 3.27 & 0.71 & 0.792 \\
& Organizational Identification & 3 & 3.54 & 0.83 & 0.679 \\
\hline
\end{tabular}

According to the findings in Table 1, Cronbach $\alpha$ coefficients of all sub-dimensions in Organizational Cynicism Scale are higher than 0.70, which indicates a high reliability (Ozdamar, 1999). Similarly, Cronbach $\alpha$ coefficient of cognitivebehavioral-affective organizational identification is higher than 0.70 , thus indicating a reliable value. Finally, Cronbach $\alpha$ coefficient of perceived organizational external prestige was calculated as 0.679 , thus indicating an acceptable level of reliability (Ozdamar, 1999). Therefore, it was concluded that the data obtained using Organizational Cynicism Scale and Academics' Organizational Identification Scale were reliable for the present study.

Based on the consensus in the literature, mean attitude scores in a 5-point Likert types scale can be roughly evaluated as "1.00-1.80: Very Low", "1.81-2.60: Low”, "2.61-3.40: Moderate", "3.41-4.20: High" and "4.21-5.00: Very High" (Tekin, 1993). In this respect, it can be inferred from mean sub-dimension scores in Table 1 that academics' levels of cognitive cynicism attitudes are low, while their affective and behavioral cynicism attitudes are at a moderate level. In addition, their levels of cognitive-behavioral-affective organizational identification are at a moderate level, whereas their levels of perceived organizational external prestige are high. Frequency and percentage values of variables in the personal information form are given in Table 2.

Table 2: Frequency and Percentages of Demographic Variables

\begin{tabular}{lcc}
\hline Gender & Frequency & $\begin{array}{c}\text { Percentage } \\
\text { (\%) }\end{array}$ \\
\hline Female & 19 & 17.9 \\
Male & 87 & 82.1 \\
Total & 106 & 100.0 \\
\hline Marital Status & Frequency & Percentage \\
& (\%) \\
\hline Married & 64 & 60.4 \\
Single & 42 & 39.6 \\
Total & 106 & 100.0 \\
\hline Does your institution offer financial aid for your & Frequency & Percentage \\
academic activities (congress, symposium etc.)? & 35 & $\mathbf{( \% )}$ \\
\hline Yes & 17 & 33.1 \\
No & 54 & 16.0 \\
Partially & 106 & 50.9 \\
Total & & 100.0 \\
\hline
\end{tabular}




\begin{tabular}{|c|c|c|}
\hline $\begin{array}{l}\text { Does your institution give permission when you ask } \\
\text { for leave for your academic research? }\end{array}$ & Frequency & $\begin{array}{l}\text { Percentage } \\
(\%)\end{array}$ \\
\hline Yes & 68 & 64.2 \\
\hline No & 6 & 5.7 \\
\hline Partially & 32 & 30.2 \\
\hline Total & 106 & 100.0 \\
\hline $\begin{array}{l}\text { Does your institution provide you with sufficient } \\
\text { physical facilities? }\end{array}$ & Frequency & $\begin{array}{l}\text { Percentage } \\
(\%)\end{array}$ \\
\hline Yes & 47 & 44.3 \\
\hline No & 59 & 55.7 \\
\hline Total & 106 & 100.0 \\
\hline $\begin{array}{l}\text { What is the status of the place where your institution } \\
\text { is located? }\end{array}$ & Frequency & $\begin{array}{l}\text { Percentage } \\
(\%)\end{array}$ \\
\hline Province & 49 & 46.2 \\
\hline Metropolitan City & 57 & 53.8 \\
\hline Total & 106 & 100.0 \\
\hline What is your academic title? & Frequency & $\begin{array}{c}\text { Percentage } \\
\text { (\%) }\end{array}$ \\
\hline Prof. Dr. & 4 & 3.8 \\
\hline Asst. Prof. & 22 & 20.8 \\
\hline Dr. & 26 & 24.5 \\
\hline Research Assistant & 42 & 39.6 \\
\hline Instructor & 12 & 11.3 \\
\hline Total & 106 & 100.0 \\
\hline
\end{tabular}

Table 2 demonstrates that while 19 participants (17.9\%) are female, 87 of them (82.1\%) are male. 64 participants (60.4\%) are married, whereas 42 of them (39.6\%) are single. Additionally, 4 professors, 22 associate professors, 26 assistant professors, 42 research assistants and 12 academicians participated in the study. While $33.1 \%$ of the academics stated that their institution offered full financial aid for papers presented at a congress and symposium, $16 \%$ of them stated that they were able to receive no financial aid, and 50.9\% of them stated that they managed to receive partial financial aid for their academic activities. $44.3 \%$ of the academics believed that physical facilities in their institution were sufficient, $55.7 \%$ of them found physical their facilities insufficient.

Mann-Whitney U test was used to analyze whether academicians' levels of organizational cynicism and identification displayed significant differences in terms of gender (Table 3).

Table 3: Mann-Whitney $U$ test results in terms of gender

\begin{tabular}{|c|c|c|c|c|c|c|}
\hline Sub-dimensions & Gender & $\mathbf{N}$ & Median & $\begin{array}{c}\text { Mann-Whitney U } \\
\text { Stats }\end{array}$ & $\begin{array}{c}\mathrm{Z} \\
\text { Statistics }\end{array}$ & $\mathbf{p}$ \\
\hline \multirow{2}{*}{ Cognitive Cynicism } & Female & 19 & 2.40 & \multirow{2}{*}{805.0} & \multirow{2}{*}{-.178} & \multirow{2}{*}{.859} \\
\hline & Male & 87 & 2.60 & & & \\
\hline \multirow{2}{*}{ Affective Cynicism } & Female & 19 & 2.25 & \multirow{2}{*}{799.0} & \multirow{2}{*}{-.228} & \multirow{2}{*}{.820} \\
\hline & Male & 87 & 2.50 & & & \\
\hline \multirow{2}{*}{ Behavioral Cynicism } & Female & 19 & 2.75 & \multirow{2}{*}{788.0} & \multirow{2}{*}{-.319} & \multirow{2}{*}{.750} \\
\hline & Male & 87 & 2.75 & & & \\
\hline Sub-dimensions & Gender & $\mathbf{N}$ & Median & $\begin{array}{c}\text { Mann-Whitney U } \\
\text { Stats }\end{array}$ & $\begin{array}{c}\mathrm{Z} \\
\text { Statistics }\end{array}$ & $\mathbf{p}$ \\
\hline \multirow{2}{*}{$\begin{array}{l}\text { Cognitive-Behavioral-Affective } \\
\text { Identification }\end{array}$} & Female & 19 & 3.30 & \multirow{2}{*}{752.0} & \multirow{2}{*}{-.614} & \multirow{2}{*}{.539} \\
\hline & Male & 87 & 3.40 & & & \\
\hline Perceived Organizational & Female & 19 & 3.33 & \multirow{2}{*}{698.5} & \multirow{2}{*}{-1.063} & \multirow{2}{*}{.288} \\
\hline External Prestige & Male & 87 & 3.67 & & & \\
\hline
\end{tabular}

It is evident in Table 3 that no significant differences were found between academicians' mean organizational cynicism and identification sub-dimension scores in terms gender $(p>0.05)$. It can be thus said that gender does not significantly influence academics' levels of organizational cynicism and identification.

Mann-Whitney U test was used to analyze whether academics' levels of organizational cynicism and identification displayed significant differences in terms of marital status (Table 4). 
Table 4: Mann-Whitney $U$ test results in terms of marital status

\begin{tabular}{|c|c|c|c|c|c|c|}
\hline Sub-dimensions & $\begin{array}{l}\text { Marital } \\
\text { Status }\end{array}$ & $\mathbf{N}$ & Median & $\begin{array}{c}\text { Mann-Whitney U } \\
\text { Stats } \\
\end{array}$ & $\begin{array}{c}\mathrm{Z} \\
\text { Statistics }\end{array}$ & $\mathbf{p}$ \\
\hline \multirow{2}{*}{ Cognitive Cynicism } & Married & 64 & 2.40 & \multirow{2}{*}{1182.5} & \multirow{2}{*}{-1.046} & \multirow{2}{*}{.295} \\
\hline & Single & 42 & 2.80 & & & \\
\hline \multirow{2}{*}{ Affective Cynicism } & Married & 64 & 2.50 & \multirow{2}{*}{1111.0} & \multirow{2}{*}{-1.514} & \multirow{2}{*}{.130} \\
\hline & Single & 42 & 2.75 & & & \\
\hline \multirow{2}{*}{ Behavioral Cynicism } & Married & 64 & 2.75 & \multirow{2}{*}{1269.0} & \multirow{2}{*}{-.487} & \multirow{2}{*}{.626} \\
\hline & Single & 42 & 2.75 & & & \\
\hline Sub-dimensions & $\begin{array}{c}\text { Marital } \\
\text { Status }\end{array}$ & $\mathbf{N}$ & Median & $\begin{array}{l}\text { Mann-Whitney U } \\
\text { Stats }\end{array}$ & $\begin{array}{c}\mathbf{Z} \\
\text { Statistics }\end{array}$ & $\mathbf{p}$ \\
\hline \multirow{2}{*}{$\begin{array}{l}\text { Cognitive-Behavioral-Affective } \\
\text { Identification }\end{array}$} & Married & 64 & 3.40 & \multirow{2}{*}{1208.5} & \multirow{2}{*}{-.876} & \multirow{2}{*}{.381} \\
\hline & Single & 42 & 3.10 & & & \\
\hline \multirow{2}{*}{$\begin{array}{l}\text { Perceived Organizational External } \\
\text { Prestige }\end{array}$} & Married & 64 & 3.67 & \multirow{2}{*}{1084.5} & \multirow{2}{*}{-1.690} & \multirow{2}{*}{.091} \\
\hline & Single & 42 & 3.33 & & & \\
\hline
\end{tabular}

It can be clearly seen in Table 4 that no significant differences were observed between academics' mean organizational cynicism and identification sub-dimension scores in terms marital status ( $\mathrm{p}>.05)$. Therefore, it is not surprising that marital status does not significantly influence their levels of organizational cynicism and identification.

Kruskal Wallis test was used to analyze whether academics' levels of organizational cynicism and identification displayed significant differences in terms of financial aid provided by the institution for academic activities such as congress and symposium (Table 5).

Table 5: Kruskal Wallis test results in terms of financial aid from the institution

\begin{tabular}{|c|c|c|c|c|c|c|c|c|c|}
\hline \multirow{2}{*}{ Sub-dimensions } & \multirow{2}{*}{$\begin{array}{l}\text { Financial } \\
\text { Aid }\end{array}$} & \multirow{2}{*}{$\mathbf{N}$} & \multirow{2}{*}{ Median } & \multirow{2}{*}{ sd } & \multirow{2}{*}{$\chi^{2}$} & \multirow{2}{*}{$\mathbf{p}$} & \multicolumn{3}{|c|}{ Mann-Whitney U Test } \\
\hline & & & & & & & $\mathbf{U}$ & $\mathbf{p}$ & Groups \\
\hline \multirow{3}{*}{ Cognitive Cynicism } & Yes & 35 & 2.00 & \multirow{3}{*}{2} & \multirow{3}{*}{16.468} & \multirow{3}{*}{.000} & 106.5 & .000 & $1-2^{*}$ \\
\hline & No & 17 & 3.00 & & & & 585.0 & .002 & $1-3^{*}$ \\
\hline & Partially & 54 & 2.80 & & & & 337.5 & .100 & $2-3$ \\
\hline \multirow{3}{*}{ Cognitive Cynicism } & Yes & 35 & 2.25 & \multirow{3}{*}{2} & \multirow{3}{*}{3.703} & \multirow{3}{*}{.157} & --- & --- & --- \\
\hline & No & 17 & 2.75 & & & & --- & --- & --- \\
\hline & Partially & 54 & 2.50 & & & & --- & --- & --- \\
\hline \multirow{3}{*}{ Behavioral Cynicism } & Yes & 35 & 2.50 & \multirow{3}{*}{2} & \multirow{3}{*}{4.073} & \multirow{3}{*}{.130} & --- & --- & --- \\
\hline & No & 17 & 3.00 & & & & --- & --- & --- \\
\hline & Partially & 54 & 2.75 & & & & --- & --- & --- \\
\hline \multirow{2}{*}{ Sub-dimensions } & \multirow{2}{*}{$\begin{array}{c}\text { Financial } \\
\text { Aid }\end{array}$} & \multirow{2}{*}{$\mathbf{N}$} & \multirow{2}{*}{ Median } & \multirow{2}{*}{ sd } & \multirow{2}{*}{$\chi^{2}$} & \multirow{2}{*}{$\mathbf{p}$} & \multicolumn{3}{|c|}{ Mann-Whitney U Test } \\
\hline & & & & & & & $\mathbf{U}$ & $\mathbf{p}$ & Groups \\
\hline \multirow{3}{*}{$\begin{array}{l}\text { Cognitive-Behavioral- } \\
\text { Affective Identification }\end{array}$} & Yes & 35 & 3.60 & \multirow{3}{*}{2} & \multirow{3}{*}{5.475} & \multirow{3}{*}{.065} & --- & --- & --- \\
\hline & No & 17 & 2.90 & & & & --- & --- & --- \\
\hline & Partially & 54 & 3.25 & & & & --- & --- & --- \\
\hline \multirow{3}{*}{$\begin{array}{l}\text { Perceived Organizational } \\
\text { External Prestige }\end{array}$} & Yes & 35 & 3.67 & \multirow{3}{*}{2} & \multirow{3}{*}{7.259} & & 188.0 & .031 & $1-2$ \\
\hline & No & 17 & 3.33 & & & .027 & 846.5 & .404 & $1-3$ \\
\hline & Partially & 54 & 3.83 & & & & 270.5 & .011 & $2-3^{*}$ \\
\hline
\end{tabular}

When Kruskal-Wallis test results concerning organizational cynicism sub-dimensions are analyzed in Table 5 , it can be observed that academics' levels of affective and behavioral cynicism did not display any significant differences based on the financial aid provided by the institution ( $p>05)$. On the other hand, their levels of cognitive cynicism display a significant difference based on the financial aid provided by the institution $\left(\chi^{2}=16.468, p<.05\right)$. In order to identify the source of this difference, a Mann-Whitney U test with Bonferrroni correction was used for a binary comparison among groups. Since three binary comparison tests were performed, the level of significance was taken as $.05 / 3=.017$ as a result of Bonferroni correction. Accordingly, the findings obtained from Mann-Whitney U test with Bonferrroni correction and mean group scores (median values) in Table 5 demonstrate that academics who could not receive financial aid from their institution for their academic activities had a significantly higher level of cognitive cynicism compared to those who received financial aid $(\mathrm{p}<.017)$. These findings also demonstrate that academicians who received partial financial aid from their institution for their academic activities had a significantly higher level of cognitive cynicism compared to those who received full financial aid $(\mathrm{p}<.017)$.

It can be also be understood from Kruskal-Wallis test results concerning organizational identification sub-dimensions in Table 5 that academics' levels of cognitive-behavioral-affective organizational identification did not display any 
significant differences in terms of financial aid provided by the institution ( $p>.05)$. On the contrary, academics' responses made it clear that perceived organizational external prestige displayed differences in terms of financial aid $\left(\chi^{2}=7.259, \mathrm{p}<.05\right)$. According to the findings of Mann-Whitney $U$ test with Bonferroni correction and group median values, academics who received partial financial aid from their institution for their academic activities had a significantly higher level of perceived organizational external prestige compared to those who received no financial aid $(\mathrm{p}<.017)$.

Kruskal Wallis test was used to analyze whether academics' levels of organizational cynicism and identification displayed significant differences in terms of institution's permission of leave for academic research (Table 6).

Table 6: Kruskal Wallis test results in terms of institution's permission of value for academic research

\begin{tabular}{|c|c|c|c|c|c|c|c|c|c|}
\hline \multirow{2}{*}{ Sub-dimensions } & \multirow{2}{*}{$\begin{array}{l}\text { Permission of leave } \\
\text { for academic } \\
\text { research }\end{array}$} & \multirow{2}{*}{$\mathbf{N}$} & \multirow{2}{*}{ Median } & \multirow{2}{*}{ sd } & \multirow{2}{*}{$\chi^{2}$} & \multirow[b]{2}{*}{$\mathbf{p}$} & \multicolumn{3}{|c|}{ Mann-Whitney U Test } \\
\hline & & & & & & & $\mathbf{U}$ & p & Groups \\
\hline \multirow{3}{*}{ Cognitive Cynicism } & Yes & 68 & 2.30 & \multirow{3}{*}{2} & \multirow{3}{*}{10.616} & \multirow{3}{*}{.005} & 68.0 & .007 & $1-2^{*}$ \\
\hline & No & 6 & 3.30 & & & & 797.5 & .031 & $1-3$ \\
\hline & Partially Positive & 32 & 2.90 & & & & 52.0 & .077 & $2-3$ \\
\hline \multirow{3}{*}{ Cognitive Cynicism } & Yes & 68 & 2.50 & \multirow{3}{*}{2} & \multirow{3}{*}{3.714} & \multirow{3}{*}{.156} & --- & --- & --- \\
\hline & No & 6 & 2.75 & & & & --- & --- & --- \\
\hline & Partially Positive & 32 & 2.63 & & & & --- & --- & --- \\
\hline \multirow{3}{*}{ Behavioral Cynicism } & Yes & 68 & 2.50 & \multirow{3}{*}{2} & \multirow{3}{*}{2.464} & \multirow{3}{*}{.292} & --- & --- & --- \\
\hline & No & 6 & 2.75 & & & & --- & --- & --- \\
\hline & Partially Positive & 32 & 2.75 & & & & --- & --- & --- \\
\hline \multirow[b]{2}{*}{ Sub-dimensions } & \multirow{2}{*}{$\begin{array}{c}\text { Permission of leave } \\
\text { for academic } \\
\text { research }\end{array}$} & \multirow[b]{2}{*}{$\mathbf{N}$} & \multirow[b]{2}{*}{ Median } & \multirow[b]{2}{*}{ sd } & \multirow[b]{2}{*}{$\chi^{2}$} & \multirow[b]{2}{*}{$\mathbf{p}$} & \multicolumn{3}{|c|}{ Mann-Whitney U Test } \\
\hline & & & & & & & $\mathbf{U}$ & $\mathbf{p}$ & Groups \\
\hline Cognitive- & Yes & 68 & 3.40 & & & & --- & --- & --- \\
\hline Behavioral-Affective & No & 6 & 3.35 & 2 & .587 & .746 & --- & --- & --- \\
\hline Identification & Partially Positive & 32 & 3.15 & & & & --- & --- & --- \\
\hline Perceived & Yes & 68 & 3.33 & & & & --- & --- & --- \\
\hline Organizational & No & 6 & 3.67 & 2 & 2.916 & .233 & --- & --- & --- \\
\hline External Prestige & Partially Positive & 32 & 3.67 & & & & --- & --- & --- \\
\hline
\end{tabular}

The findings in Table 6 indicate that only mean cognitive cynicism scores, which is one of the sub-dimension in organizational cynicism, displayed a significant difference in terms of institution's permission of leave for academic research $\left(\chi^{2}=10.616, p<.05\right)$. Similarly, when the findings of Mann-Whitney U test with Bonferroni correction and group median values are taken into account, academics who were not permitted to leave for academic research had a significantly higher level of cognitive cynicism compared to those who were given a permission to leave $(\mathrm{p}<.017)$.

The findings in Table 6 also indicate that academicians' mean organizational identification scores in both subdimensions displayed no significant differences in terms of permission of leave for academic research ( $p>.05$ ). Therefore, it can be stated that the institution's permission of leave for academic research do not significantly influence academics' level of organizational identification.

Mann-Whitney U test was used to analyze whether academicians' levels of organizational cynicism and identification displayed significant differences in terms of sufficient physical facilities in their institution (Table 7).

Table 7: Mann-Whitney U test results in terms of sufficient physical facilities

\begin{tabular}{|c|c|c|c|c|c|c|}
\hline Sub-dimensions & $\begin{array}{c}\text { Sufficient Physical } \\
\text { Facilities }\end{array}$ & $\mathbf{N}$ & Median & $\begin{array}{c}\text { Mann-Whitney U } \\
\text { Stats }\end{array}$ & $\begin{array}{c}\mathrm{Z} \\
\text { Stats }\end{array}$ & $\mathbf{p}$ \\
\hline \multirow{2}{*}{ Cognitive Cynicism } & Yes & 47 & 2.00 & \multirow{2}{*}{652.0} & \multirow{2}{*}{-4.685} & \multirow{2}{*}{.000} \\
\hline & No & 59 & 2.80 & & & \\
\hline \multirow{2}{*}{ Affective Cynicism } & Yes & 47 & 2.25 & \multirow{2}{*}{905.0} & \multirow{2}{*}{-3.080} & \multirow{2}{*}{.002} \\
\hline & No & 59 & 2.75 & & & \\
\hline \multirow{2}{*}{ Behavioral Cynicism } & Yes & 47 & 2.50 & \multirow{2}{*}{961.0} & \multirow{2}{*}{-2.719} & \multirow{2}{*}{.007} \\
\hline & No & 59 & 2.75 & & & \\
\hline Sub-dimensions & $\begin{array}{c}\text { Sufficient Physical } \\
\text { Facilities }\end{array}$ & $\mathbf{N}$ & Median & $\begin{array}{c}\text { Mann-Whitney U } \\
\text { Stats }\end{array}$ & $\begin{array}{c}\mathrm{Z} \\
\text { Stats }\end{array}$ & $\mathbf{p}$ \\
\hline \multirow{2}{*}{$\begin{array}{l}\text { Cognitive-Behavioral- } \\
\text { Affective Identification }\end{array}$} & Yes & 47 & 3.60 & \multirow{2}{*}{958.0} & \multirow{2}{*}{-2.728} & \multirow{2}{*}{.006} \\
\hline & No & 59 & 3.00 & & & \\
\hline Perceived Organizational & Yes & 47 & 3.67 & \multirow{2}{*}{1358.5} & \multirow{2}{*}{-.179} & \multirow{2}{*}{.858} \\
\hline External Prestige & No & 59 & 3.67 & & & \\
\hline
\end{tabular}


It can be understood from Table 7 that academics' mean cognitive, affective and behavioral cynicism scores displayed differences in terms of sufficient physical facilities in their academic institution $(\mathrm{p}<.05)$. However, when mean group scores (median values) are taken into account, academics who found physical facilities insufficient in their academic institution had a significantly higher level of cognitive, affective and behavioral cynicism compared to those who find physical facilities sufficient in their academic institution.

In addition, Table 7 suggests that academics' mean cognitive-affective-behavioral identification scores displayed significant differences in terms of sufficient physical facilities in an academic institution $(\mathrm{p}<.05)$. When median values are analyzed, it can be observed that academics who found physical facilities sufficient in their academic institution had a significantly higher level of cognitive-affective-behavioral identification compared to those who found physical facilities insufficient in their academic institution.

Mann-Whitney U test was used to analyze whether academics' levels of organizational cynicism and identification displayed significant differences in terms of the status of the place where the institution is located (Table 8).

Table 8: Mann-Whitney $U$ test results in terms of status of the location

\begin{tabular}{|c|c|c|c|c|c|c|}
\hline Sub-dimensions & $\begin{array}{l}\text { Status of } \\
\text { Location }\end{array}$ & $\mathbf{N}$ & Median & $\begin{array}{c}\text { Mann-Whitney U } \\
\text { Stats } \\
\end{array}$ & $\begin{array}{c}\mathrm{Z} \\
\text { Stats } \\
\end{array}$ & $\mathbf{p}$ \\
\hline \multirow{2}{*}{ Cognitive Cynicism } & Province & 49 & 2.80 & \multirow{2}{*}{1224.5} & \multirow{2}{*}{-1.093} & \multirow{2}{*}{.274} \\
\hline & Metropolitan & 57 & 2.40 & & & \\
\hline \multirow{2}{*}{ Affective Cynicism } & Province & 49 & 2.75 & \multirow{2}{*}{1126.5} & \multirow{2}{*}{-1.721} & \multirow{2}{*}{.085} \\
\hline & Metropolitan & 57 & 2.25 & & & \\
\hline \multirow{2}{*}{ Behavioral Cynicism } & Province & 49 & 2.75 & \multirow{2}{*}{1179.5} & \multirow{2}{*}{-1.382} & \multirow{2}{*}{.167} \\
\hline & Metropolitan & 57 & 2.50 & & & \\
\hline Sub-dimensions & $\begin{array}{l}\text { Status of } \\
\text { Location }\end{array}$ & $\mathbf{N}$ & Median & $\begin{array}{c}\text { Mann-Whitney } \\
\text { U Stats }\end{array}$ & $\begin{array}{c}\mathrm{Z} \\
\text { Stats }\end{array}$ & $\mathbf{p}$ \\
\hline \multirow{2}{*}{$\begin{array}{l}\text { Cognitive-Behavioral-Affective } \\
\text { Identification }\end{array}$} & Province & 49 & 3.00 & \multirow{2}{*}{991.0} & \multirow{2}{*}{-2.573} & \multirow{2}{*}{.010} \\
\hline & Metropolitan & 57 & 3.60 & & & \\
\hline Perceived Organizational & Province & 49 & 3.67 & \multirow{2}{*}{1242.0} & \multirow{2}{*}{-.987} & \multirow{2}{*}{.324} \\
\hline External Prestige & Metropolitan & 57 & 3.33 & & & \\
\hline
\end{tabular}

Mann-Whitney U test results in Table 8 demonstrate that academics' mean cognitive, affective and behavioral cynicism scores did not display any significant differences in terms of the status of the place where the institution is located ( $\mathrm{p}>$.05). Therefore, whether an academic institution is located in a province or metropolitan city does not have a statistically significant impact on academics' levels of organizational cynicism.

The findings in Table 8 also demonstrate that academics' levels of cognitive-behavioral-affective organizational identification displayed significant differences in terms of the status of the location $(p<.05)$. In addition, given the median values, academics who work for an academic institution located in a metropolitan city had a significantly higher level of cognitive-behavioral-affective organizational identification compared to those who work for an academic institution located in a province. On the other hand, academicians' perceived organizational external prestige did not display significant difference in terms of the status of the location ( $p>.05)$.

Finally, Kruskal Wallis test was used to analyze whether academicians' levels of organizational cynicism and identification displayed significant differences in terms of their academic title (Table 9).

Table 9: Kruskal Wallis test results in terms of academic title

\begin{tabular}{lcccccc}
\hline Sub-dimensions & Academic Title & N & Median & sd & $\chi^{2}$ & p \\
\hline \multirow{3}{*}{ Cognitive Cynicism } & Prof. Dr. & 4 & 2.00 & & & \\
& Assoc. Prof. Dr. & 22 & 2.60 & & & \\
& Dr. & 26 & 2.40 & 4 & 4.588 & .332 \\
& Research Assistant & 42 & 2.80 & & & \\
\hline \multirow{2}{*}{ Affective Cynicism } & Instructor & 12 & 2.30 & & & \\
& Prof. Dr. & 4 & 2.13 & & & \\
& Assoc. Prof. Dr. & 22 & 2.63 & & & \\
& Dr. & 26 & 2.25 & 4 & \multirow{2}{*}{6.483} & .166 \\
& Research Assistant & 42 & 2.75 & & & \\
\hline
\end{tabular}


Table 9. Continued

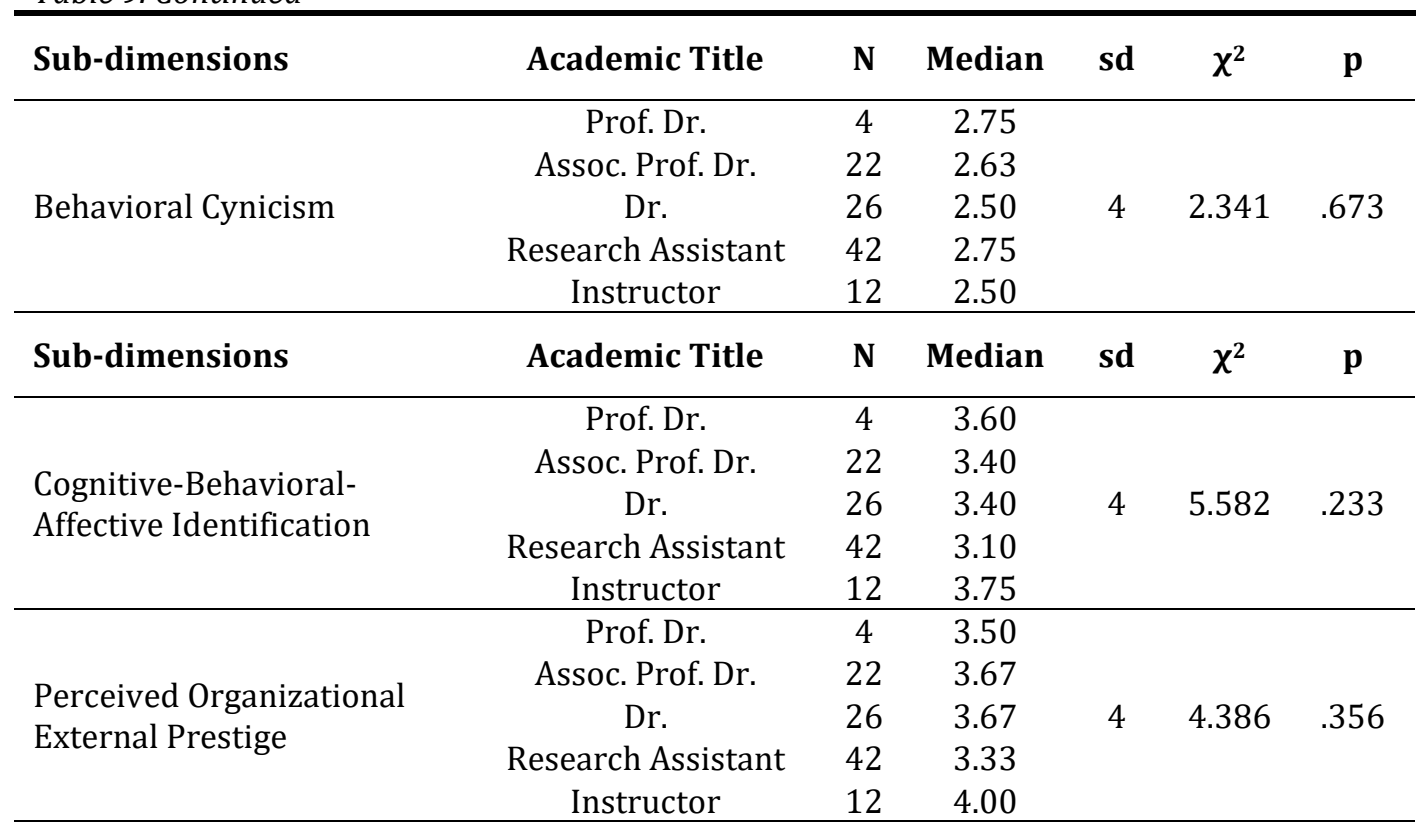

Table 9 indicates that academics' mean cognitive, affective and behavioral cynicism scores did not display any significant differences in terms of their academic title ( $p>.05)$. Thus, it is evident that academics' titles do not have any significant impact on their levels of organizational cynicism.

The findings in Table 9 also indicate that academics' mean organizational identification scores in both sub-dimension did not display any significant differences in terms of academic title ( $p>.05)$. In other words, academics' academic title does not have a significant impact on their levels of organizational identification.

Spearman order correlation coefficients were calculated in order to identify whether there were significant correlations among academics' levels of cognitive, affective and behavioral cynicism, which are sub-dimensions of organizational cynicism.

Firstly, any significant correlations among academics' organizational cynicism sub-dimensions were analyzed, and Spearman correlation coefficients were obtained as given in Table 10.

Table 10: Spearman Correlation Coefficients of Organizational Cynicism Sub-dimensions

\begin{tabular}{ccccc}
\hline & & $\begin{array}{c}\text { Cognitive } \\
\text { Cynicism }\end{array}$ & $\begin{array}{c}\text { Affective } \\
\text { Cynicism }\end{array}$ & $\begin{array}{c}\text { Behavioral } \\
\text { Cynicism }\end{array}$ \\
\hline & $\mathrm{r}_{\mathrm{s}}$ & 1,00 & $\mathbf{. 8 0 5}$ & $\mathbf{7 4 1}$ \\
Cognitive Cynicism & $\mathrm{p}$ & & $\mathbf{0 0 0}$ & $\mathbf{0 0 0}$ \\
& $\mathrm{N}$ & 106 & 106 & 106 \\
\hline \multirow{3}{*}{ Affective Cynicism } & $\mathrm{r}_{\mathrm{s}}$ & & 1.00 & $\mathbf{7 8 6}$ \\
& $\mathrm{p}$ & & 106 & $\mathbf{0 0 0}$ \\
& $\mathrm{N}$ & & & 106 \\
\hline \multirow{2}{*}{ Behavioral Cynicism } & $\mathrm{r}_{\mathrm{s}}$ & & & 1.00 \\
& $\mathrm{p}$ & & & 106 \\
\hline
\end{tabular}

According to Table 10, highly positive significant correlations were found between academics' levels of cognitive and affective cynicism $\left(\mathrm{r}_{\mathrm{s}}=.805, \mathrm{p} 0.05\right)$, levels of cognitive and behavioral cynicism $\left(\mathrm{r}_{\mathrm{s}}=.741, \mathrm{p}<.05\right)$, and levels of affective and behavioral cynicism $\left(\mathrm{r}_{\mathrm{s}}=.786, \mathrm{p}<.05\right)$.

Spearman order correlation coefficients were calculated in order to identify whether there were significant correlations among academics' levels of organizational identification sub-dimensions, and the findings are given in Table 11. 
Table 11: Spearman Correlation Coefficients of Organizational Identification Sub-dimensions

\begin{tabular}{|c|c|c|c|}
\hline & & $\begin{array}{c}\text { Cognitive-Behavioral- } \\
\text { Affective Identification }\end{array}$ & $\begin{array}{c}\text { Perceived Organizational } \\
\text { External Prestige }\end{array}$ \\
\hline \multirow{3}{*}{ Cognitive-Behavioral-Affective Identification } & $\mathrm{r}_{\mathrm{s}}$ & 1.00 & .435 \\
\hline & $\mathrm{p}$ & & .000 \\
\hline & $\mathrm{N}$ & 106 & 106 \\
\hline \multirow{3}{*}{$\begin{array}{c}\text { Perceived Organizational External } \\
\text { Prestige }\end{array}$} & $\mathrm{r}_{\mathrm{s}}$ & & 1.00 \\
\hline & $\mathrm{p}$ & & \\
\hline & $\mathrm{N}$ & & 106 \\
\hline
\end{tabular}

It can be observed in Table 11 that a moderately significant positive correlation was found between academics' levels of cognitive-behavioral-affective organizational identification and perceived organizational external prestige $\left(\mathrm{r}_{\mathrm{s}}=.805\right.$, $\mathrm{p}<.05)$.

Finally, Spearman order correlation coefficients were calculated in order to identify whether there were significant correlations between academics' levels of organizational cynicism and identification sub-dimensions, and the findings are given in Table 12.

Table 12: Spearman Correlation Coefficients between Organizational Cynicism and Identification

\begin{tabular}{|c|c|c|c|}
\hline & & $\begin{array}{l}\text { Cognitive-Behavioral- } \\
\text { Affective Identification }\end{array}$ & $\begin{array}{c}\text { Perceived Organizational } \\
\text { External Prestige }\end{array}$ \\
\hline \multirow{3}{*}{ Cognitive Cynicism } & $\mathrm{r}_{\mathrm{s}}$ & -0.436 & -0.077 \\
\hline & $\mathrm{p}$ & 0.000 & 0.430 \\
\hline & $\mathrm{N}$ & 106 & 106 \\
\hline \multirow{3}{*}{ Affective Cynicism } & $\mathrm{r}_{\mathrm{s}}$ & -0.383 & -0.047 \\
\hline & $\mathrm{p}$ & 0.000 & 0.629 \\
\hline & $\mathrm{N}$ & 106 & 106 \\
\hline \multirow{3}{*}{ Behavioral Cynicism } & $\mathrm{r}_{\mathrm{s}}$ & -0.432 & -0.119 \\
\hline & $\mathrm{p}$ & 0.000 & 0.223 \\
\hline & $\mathrm{N}$ & 106 & 106 \\
\hline
\end{tabular}

It is evident in Table 12 that while there was a moderately significant negative correlation between academics' levels of cognitive cynicism and cognitive-behavioral-affective organizational identification $\left(\mathrm{r}_{\mathrm{s}}=-.436, \mathrm{p}<.05\right)$, a significant correlation was not found between levels of cognitive cynicism and perceived organizational external prestige ( $p>.05$ ).

In addition, while a moderately significant correlation was observed between academics' levels of cognitive cynicism and cognitive-behavioral-affective organizational identification $\left(\mathrm{r}_{\mathrm{s}}=-.383, \mathrm{p}<.05\right)$, no significant correlations were observed between academics' levels of affective cynicism and perceived organizational external prestige ( $p>.05)$.

Finally, Table 12 demonstrates that when correlations between academics' levels of behavioral cynicism and organizational identification sub-dimensions are taken into account, a moderately significant negative correlation was found between academicians' levels of behavioral cynicism and cognitive-behavioral-affective organizational identification $\left(\mathrm{r}_{\mathrm{s}}=-.432, \mathrm{p}<.05\right)$. However, no significant correlations were observed between academics' levels of behavioral cynicism and perceived organizational external prestige ( $p>05)$.

In short, it is safe to argue based on these findings that a moderately significant negative correlation was found between academics' organizational cynicism sub-dimensions and cognitive-behavioral-affective organizational identification sub-dimensions. In this respect, it can be concluded that academics' levels of organizational cynicism moderately decrease when their levels of cognitive-behavioral-affective organizational identification increase. On the other hand, there is no significant correlation between perceived organizational external prestige and any organizational cynicism sub-dimension.

\section{Discussion and Conclusion}

The present study demonstrated that academics' levels of organizational cynicism did not display any significant differences in terms of gender.

A similar study also indicated that male and female staff's mean cynicism scores did not display any significant differences (Kepoglu et al., 2015). Another study, too, reported no significant differences between male and female individuals in terms of organizational cynicism (Yavuz \& Beduk, 2016). However, a study by Ekici, Hacicaferoglu \& Caliskan (2017) did not find any significant differences between male and female officials in terms of cognitive cynicism in the organizations affiliated with Ministry of Youth and Sports. 
Another finding of the present study revealed that academicians' mean organizational cynicism sub-dimension scores did not display any significant differences in terms of marital status.

A study on married and single staff's organizational cynicism attitudes did not display any significant differences (Ekici, Hacicaferoglu \& Caliskan, 2017). Another similar study also reported that there were no significant differences between married and single individuals in terms of organizational cynicism (Yavuz \& Beduk, 2016). However, it is also possible to find studies which do not overlap the findings in the present study. For instance, significant differences were observed between married and single staff in the sports enterprises in terms of general cynicism and cognitive cynicism sub-dimension (Ceyhun, Malkoc \& Arslan, 2017).

It was found out in the present study that academics' cognitive, affective and behavioral cynicism attitudes did not display any significant differences in terms of academic title.

A similar study did not observe any significant differences between general cynicism and other sub-dimensions in terms of academic title (Caliskan \& Ekici, 2017). On the other hand, another study demonstrated that staff with different titles had significantly different mean cynicism scores (Kepoglu et al., 2015).

Another important finding in the present study is related to the fact that a moderately significant negative correlation was found between academics' levels of cognitive cynicism attitudes and cognitive-behavioral-affective organizational identification, while no significant correlations were found between their cognitive cynicism attitudes and perceived organizational external prestige. In addition, a moderately significant negative correlation was observed between instructors' levels of affective cynicism attitudes and cognitive-behavioral-affective organizational identification, whereas no significant correlations were observed between their affective cynicism attitudes and perceived organizational external prestige. In a similar vein, while a moderately significant negative correlation was observed between academics' levels of behavioral cynicism attitudes and cognitive-behavioral-affective organizational identification, no significant correlations were observed between their behavioral cynicism attitudes and perceived organizational external prestige.

It is possible to encounter studies which support the findings in the present study. A negative and significant correlation was found between organizational cynicism and identification sub-dimensions (Ayik, Sayir \& Bilici, 2016), which completely overlaps the findings of the present study. Another study, too, reported a low negative correlation between organizational commitment and organizational cynicism (Ekici, Hacicaferoglu \& Caliskan, 2017). It was also demonstrated that physical education and sports teachers' perception of organizational cynicism are predictors of their organizational commitment (Okcu, Sahin \& Sahin, 2015). In another study, a strong negative correlation was revealed between participants' perception of organizational justice and organizational cynicism attitudes (Mavibas \& Belli, 2018).

A study on workers indicated on teachers found out a highly significant negative correlation between perception of organizational commitment and cynicism, while a moderately significant negative correlation was found in terms of organizational opposition (Yildiz, 2013). As far as the correlation between perceived organizational support and identification is concerned, a low significant positive correlation was found between coaches' perceived organizational support and identification behaviors (Sahin \& Reyhan, 2017). Another study demonstrated that employees who found their organization's external prestige positive had a higher level of organizational identification (Karabey \& Iscan, 2007). In addition, a significantly positive correlation was observed among organizational confidence, identification and citizenship behaviors (Tokgoz \& Seymen Aytemiz, 2013). In addition, it is often stressed in the literature that a significantly positive correlation can be observed between organizational commitment and organizational identification, individual organizational harmony and job satisfaction (Sokmen \& Biyik, 2016).

It was indicated in a study on pre-school institution teachers that a moderately significant positive correlation was found between their perceptions of organizational identification and proactive behavior and that organization identification was a predictor of proactive behaviors (Ozdemir et al., 2018). A significant positive correlation was found between organizational identification and organizational socialization and its sub-dimensions, which are job training, coworker support and future prospects (Aliyev \& Isik, 2014).

In the present study, no significant differences were observed between academics' mean organization cynicism and identification sub-dimension scores in terms of gender. It can be inferred from this finding that organizational cynicism and identification did not display any significant differences between male and female academics. Similarly, no significant differences were found between academics' mean organizational cynicism sub-dimension scores and organizational identification sub-dimension scores in terms of marital status, which demonstrates that their levels of organizational cynicism and identification were not influenced by marital status.

Another important finding in the present study is that there were no significant differences between academics' levels of affective and behavioral cynicism in terms of the financial aid provided by their academic institution. As for the findings related to organizational identification sub-dimension, academics' levels of cognitive-behavioral-affective organizational identification did not display any significant differences in terms of the financial aid provided by their academic institution. It was already mentioned above that sufficiency of physical facilities in the institution had a 
significant impact on academics' organizational cynicism attitudes. Academics who believed that their institutions did not offer them sufficient physical facilities had a significantly higher level of cognitive, affective and behavioral cynicism compared to those who believed that their institutions provided them with sufficient physical facilities.

No significant differences were observed among academics with different academic titles in terms of their organizational cynicism attitudes. Therefore, it can be argued that academics' titles had no significant impact on their levels of organizational cynicism. A similar finding was valid for organizational identification as a moderately significant negative correlation was found between academics' organizational cynicism sub-dimensions and cognitivebehavioral-affective organizational identification sub-dimension. In this respect, it can be concluded that academics' levels of cognitive-behavioral-affective organizational identification are inversely proportional to a moderate decrease in their levels of organizational cynicism.

Despite its wide range of findings, the present study has also its limitations. For instance, the sample of the study consists of 106 academics working in the field of sports sciences, and, as a result, a more comprehensive study that will encompass academics working in different disciplines is more likely to yield more valid and generalizable results. In addition, further studies may deal with academics' levels of organizational cynicism and identification based on variables different from those used in the present study.

\section{Recommendations}

Based on the data obtained from the results of this study, following recommendations are presented.

1. The study was conducted with academics in the field of sports sciences. Data may also be collected from academicians in other departments.

2. Different demographic variables can be used in studies.

3. To eliminate the cynicism levels of academicians, a positive working environment should be created.

\section{References}

Aliyev, Y., \& Isik, M. (2014). An examination of the relationship between organizational socialization and organizational identification. Journal of Social Sciences Institute, 37(2), 131-149.

Ayik, A., Sayir, G., \& Bilici, A. (2016). Investigation of the predictor effect of organizational cynicism on organizational identification according to teachers' perceptions. Pegem Journal of Education and Training, 6(2), 233-254.

Barutcu, K. (2015). Kamu personelinin algilanan orgutsel destegin orgutsel baglilik ve orgutsel ozdeslesme duzeyleri ile iliskisini belirlemeye yonelik bir arastirma [A study on determining the relationship of perceived organizational support with organizational commitment and organizational identification levels of public personnel] (Unpublished master's thesis). Eskisehir Osmangazi University, Eskisehir, Turkey.

Brandes, P. (1997). Organizational cynicism: its nature, antecedents, and consequences (Unpublished doctoral dissertation). Maastricht University, Maastricht, The Netherlands.

Buyukozturk, S. (2010). Sosyal bilimler icin veri analizi el kitabi [Manual of data analysis for social sciences]. Ankara: Pegem.

Caliskan, K., \& Ekici, S. (2017). Spor egitimi veren yuksekogretim kurumlarindaki ogretim elemanlarinin orgutsel sinizm algilari ile orgutsel bagliliklarinin arastirilmasi [The investigation of organizational cynism and organizational commitment perceptions of academic staff at higher education institutions offering sports education]. Journal of Human Sciences, 14(2), 1674-1689.

Ceyhun, S., Malkoc, N., \& Arslan, N. (2017). Ozel spor isletmelerinde calisan personelin genel sinizm duzeylerinin incelenmesi [Personnel working in special sport facilities investigation of general cynicism levels]. National Journal of Sport Sciences, $1(2), 12-26$.

Dean, J. W., Brandes, P., \& Dharwadkar, R. (1998). Organizational cynicism. The Academy of Management Review, 23(2), 341352.

Eker, D. (2015). Ogretim elemani orgutsel ozdeslesme olcegi gecerlik ve guvenirlik calismasi [Instructor's organizational identification scale validity and reliability]. Journal of Education and Teaching Research, 4(4), 118-124.

Ekici, S., Hacicaferoglu, H., \& Caliskan, K. (2017). Genclik ve spor bakanligina bagli spor orgutlerinde calisan yoneticilerin orgutsel baglilik ve orgutsel sinizm duzeylerinin incelenmesi [The investigation of the levels of organizational commitment and organizational cynism of managers working in sports organizations affiliated to the ministry of youth and sports]. CBU Journal of Physical Education and Sport Sciences, 12(2), 40-57.

Eroglu, E. (2008). Egitim ortamlarinda etkili iletisim ve boyutlari [Effective communication and dimensions in educational environments]. In U. Demiray (Ed.), Etkili Iletisim [Effective communication]. Ankara: Pegem.

Gurbuz, S., \& Sahin, F. (2014). Sosyal bilimlerde arastirma yontemleri [Research methods in social sciences] (2 ${ }^{\text {nd }}$ Ed.). Ankara: Seckin. 
Kalagan, G. (2009). Arastirma gorevlilerinin orgutsel destek algilari ile orgutsel sinizm tutumlari arasindaki iliski [The relationship between organizational support perception of research assistants and organizational cynicism attitudes] (Unpublished master's thesis). Akdeniz University, Antalya, Turkey.

Karabey, C. N., \& Iscan, O. F. (2007). Orgutsel ozdeslesme, orgutsel imaj ve orgutsel vatandaslik davranisi iliskisi: bir uygulama [The relationship between organizational identification, organizational image and organizational citizenship behavior: an application]. Journal of Economics and Administrative Sciences, 21(2), 231-241.

Karasar, N. (2006). Scientific research method. Ankara: Nobel.

Kepoglu, A., Serarslan, M.Z., Bulgurcuoglu, A.N., Ocalmaz, S., \& Albayrak, E. (2015). Istanbul youth and sports management services cynicism level of investigation of staff. Nigde University Journal of Physical Education And Sport Sciences, 9(3), 331-350.

Mantere, S., \& Martinsuo, M. (2001). Adopting and questioning strategy: exploring the roles of cynicism and dissent. paper presented at 17 th EGOS - European Group For Organisation Studies, Colloquium, Lyon, France.

Mavibas, M., \& Belli, E. (2018). The investigation of organizational justice perception and organizational cynicism attiitudes of the academic personnel in the faculties of sports science. Etu Journal of Social Sciences Institute, 3(6), 121-133.

Metzger, M. D. (2004). A qualitative inquiry into the formation of beliefs in a police organization (Unpublished doctoral dissertation). The George Washington University, Washington, USA.

Okcu, V., Sahin, H. M., \& Sahin, E. (2015). The effects of physical education and sport teachers' perceptions about organizational cynism on organizational commitment. International Journal of Science Culture and Sport, 4, $298-313$.

Oz, U., \& Bulutlar, F. (2009). Algilanan kurumsal itibar ve kurumdan ayrilma niyeti arasindaki iliskide bir ara degisken olarak ozdeslesmenin rolu [The role of identification as an intermediate in the relationship between perceived corporate reputation and intention to leave]. Journal of Management Research, 9(1), 35-52.

Ozdamar, K. (1999). Paket programlar ile istatistiksel veri analizi 1 [Statistical data analysis with package programs 1] (2nd Printing). Eskisehir: Kaan Bookstre.

Ozdemir, T., Akgun, N., Yildiz, K., \& Cerit, Y. (2018). Ogretmenlerin orgutsel ozdeslesme ile proaktif davranis sergileme duzeyleri arasindaki iliski [Relationship between teachers' organizational identification and proactive behavior levels]. Journal of Academic Social Research, 6(78), 108-118.

Qian, Y., \& Daniels, T. D. (2008). A communication model of employee cynicism toward organizational change. Corporate Communication: An International Journal, 13(3), 319-332.

Ramaley, J. A. (2002). New truths and old verities. New Directions For Higher Education, 119, 15-22.

Sahin, E., \& Reyhan, S. (2017). An analysis of the relationship between perceived organizational support and organizational identification in coaches employed in youth services and provincial sports directorate. Journal Of International Sport Sciences, 3(1), 23-34.

Sokmen, A., \& Biyik, Y. (2016). Orgutsel baglilik, orgutsel ozdeslesme, kisi-orgut uyumu ve is tatmini iliskisi: bilisim uzmanlarina yonelik bir arastirma [The relationship between organizational commitment, organizational identification, person-organization fit, and job satisfaction: a research on it specialists]. Journal of Information Technologies, 9(2), 221227.

Tekin, H. (1993). Egitimde olcme ve degerlendirme [Measurement and evaluation in education]. Ankara: Yargi.

Tokgoz, E., \& Seymen Aytemiz, O. (2013). Relationship between organizational trust, organizational identification and organizational citizenship behavior: a study at a state hospital. Oneri, 10(39), 61-76.

Topaloglu, I. G. (2010) Isgorenlerin adalet ve etik algilari acisindan orgutsel guven ve orgutsel baglilik iliskisi [Relationship between organizational trust and organizational commitment in terms of perception of justice and ethics of employees]. Master's thesis. Atilim University, Istanbul, Turkey.

Turunc, O., \& Celik, M. (2010). Algilanan orgutsel destegin calisanlarin is-aile, aile-is catismasi, orgutsel ozdeslesme ve isten ayrilma niyetine etkisi: savunma sektorunde bir arastirma [The effects of perceived organizational support on employee-family, family-work conflict, organizational identification and leaving: a research in the defense sector]. Ataturk University Journal of the Institute of Social Sciences, 14(1), 209-232.

Yavuz, A., \& Beduk, A. (2016). The relationship between organizational cynicism and organizational commitment: a case study in the branches in Konya of a government bank. Selcuk University Journal of Social Sciences Institute, 35, $301-313$.

Yildiz, K. (2013). The relationship between organizational commitment and organizational cynicism and organizational dissent. Turkish Studies, 8(6), 853-879. 